\title{
PEMBERIAN SARI BENGKOANG TERHADAP KADAR GLUKOSA DARAH PUASA PADA PENDERITA DIABETES MELITUS TIPE 2
}

\section{GIVING SARI BENGKUANG TO THE CONTENTS OF FAST BLOOD GLUCOSE IN TYPE 2 DIABETES MELITUS}

\author{
Yunita Dwi Nunggaryati ${ }^{1}$;Ria Ambarwati ${ }^{2}$;ri Noor Mintarsih ${ }^{3}$;Sunarto ${ }^{4}$;Yuwono Setiadi ${ }^{5}$ \\ ${ }^{1}$ Mahasiswa Jurusan Gizi Politeknik Kesehatan Kemenkes Semarang \\ 2,3,4,5 Dosen Jurusan Gizi Politeknik Kesehatan Kemenkes Semarang
}

\begin{abstract}
Background : Diabetes mellitus is a condition in which blood levels in the body is high due to a disruption in the pancreas gland so the body can not produce or can not use insulin. Diabetes mellitus type 2 is a type of diabetes mellitus that does not depend on insulin or better known as non-insulin-dependent. Prevalence of Diabetes Mellitus in Central Java was ranked 2nd out of 8 new cases of PTM (Non Communicable Disease), with a percentage of $18.44 \%$. Control efforts can be done by eating high-fiber foods, one of the foods that contain fiber is high enough and potentially lower blood glucose levels, namely bengkoang.
\end{abstract}

Objective: To determine the effect of bengkoang juice on fasting blood glucose level in type 2 diabetes mellitus.

Methods : Type of quasy experiment study with pretest-posttest control group design. The population is patients of type 2 diabetes mellitus aged 40-60 years in the work area of Kedungmundu Public Health Center in April as many as 60 people. Sampling using non randomized sampling technique. The sample size is 36 people divided into 18 treatment groups and 18 control groups. Intervention given in the form ofbengkoang juice for 14 days. Multivariate test using anova repeated measured.

Results : The giving of bengkoang juice controlled by nutrient intake (energy, protein, fat, carbohydrate and fiber) showed no significant effect on decreasing fasting blood glucose level ( $p=0.344)$.

Conclusion: Bengkoang juice has no significant effect on decreasing fasting blood glucose level in type 2 diabetes mellitus.

Keywords: Bengkoang juice, fasting blood sugar

\section{ABSTRAK}

Latar Belakang :Diabetes mellitus merupakan keadaan dimana kadar darah di dalam tubuh tinggi akibat adanya gangguan pada kelenjar pankreas sehingga tubuh tidak dapat menghasilkan atau tidak dapat menggunakan insulin. Diabetes mellitus tipe 2 adalah jenis diabetes mellitus yang tidak bergantung kepada insulin atau yang lebih dikenal dengan non-insulin-dependent. Prevalensi Diabetes Mellitus di Jawa Tengah menduduki peringkat ke-2 dari 8 kasus baru PTM (Penyakit Tidak Menular), dengan persentase sebesar $18,44 \%$. Upaya pengendalian dapat dilakukan dengan mengonsumsi bahan makanan tinggi serat, salah satu bahan makanan yang mengandung serat cukup tinggi dan berpotensi menurunkan kadar glukosa darah yaitu bengkoang.

Tujuan : Mengetahui pengaruh pemberian sari bengkoang terhadap kadar glukosa darah puasa pada penderita diabetes mellitus tipe 2 .

Metode : Jenis penelitian quasi eksperimen dengan rancangan pretest-posttest control group design. Populasi yang digunakan adalah penderita diabetes mellitus tipe 2 berusia 40-60 tahun di wilayah kerja Puskesmas Kedungmundu pada bulan April sebanyak 60 orang. Pengambilan sampel dilakukan secara non randomized sampling. Jumlah sampel sebanyak 36 orang yang terbagi menjadi 18 kelompok perlakuan dan 18 kelompok kontrol. Intervensi yang diberikan berupa pemberian sari bengkoang selama 14 hari. Uji multivariat menggunakan anova repeated measured. 
Hasil : Pemberian sari bengkoang yang dikontrol oleh asupan zat gizi (energi, protein, lemak, karbohidrat dan serat) menunjukkan adanya pengaruh yang tidak signifikan terhadap penurunan kadar glukosa darah puasa $(p=0.344)$.

Kesimpulan :Pemberian sari bengkoang berpengaruh tidak signifikan terhadap penurunan kadar glukosa darah puasa pada penderita diabetes mellitus tipe 2 .

Kata Kunci : Sari bengkoang, gula darah puasa

\section{PENDAHULUAN}

Diabetes Mellitus atau yang dikenal dengan kencing manis adalah penyakit kronis dimana kadar glukosa darah di dalam tubuh tinggi (hiperglikemia) akibat gangguan pada kelenjar pankreas sehingga tubuh tidak dapat menghasilkan atau tidak dapat menggunakan insulin ${ }^{1}$. Prevalensi Diabates Mellitus pada tahun 2014 diperkirakan meningkat menjadi 8,5\% atau sekitar 422 juta orang usia dewasa. Diabetes Mellitus tanpa komplikasi menyebabkan 1,5 juta kematian pada tahun 2012 dan banyaknya kematian (43\%) terjadi di bawah usia 70 tahun. Jumlah kematian terbesar akibat glukosa darah tinggi terjadi di negara berpenghasilan menengah ke atas ( 1,5 juta) dan terendah di negara berpenghasilan rendah $(0,3 \text { juta })^{2}$.

Pada tahun 2015, sebanyak 10 juta orang di Indonesia mengalami Diabetes Mellitus dan menduduki peringkat ke-7 dengan prevalensi tertinggi di bawah China, India, Amerika Serikat, Brazil, Rusia, dan Meksiko, sedangkan prevalensi Diabetes Mellitus di Jawa Tengah menduduki peringkat ke-2 dari 8 kasus baru PTM (Penyakit Tidak Menular), yaitu sebesar $18,44 \%{ }^{34}$. Berdasarkan data Dinas Kesehatan Kota Semarang bulan Januari-Desember Tahun 2017, salah satu Puskesmas yang masuk ke dalam 10 besar persentase tertinggi kasus Diabetes Mellitus tipe 2 terdapat di Puskesmas Kedungmundu yaitu sebanyak 669 kasus. Data rekam medik Puskesmas Kedungmundu mencatat sebanyak 238 kasus baru Diabetes Mellitus tipe 2 yang datang berobat pada bulan Januari- Maret 2018.

Upaya pengendalian diabetes dapat dilakukan melalui 4 pilar yaitu meliputi edukasi, pengaturan makan, peningkatan aktivitas fisik, dan terapi farmakologis. Prinsip dalam melakukan pengaturan makan salah satunya dengan mengonsumsi makanan tinggi serat ${ }^{5}$. Serat berperan terhadap kesehatan tubuh seperti dalam proses pengontrolan kadar glukosa darah, sehingga dianjurkan mengonsumsi serat dalam sehari sebanyak sekitar 20-35 gram per hari. Sumber makanan yang tinggi serat terdapat pada buah dan sayur serta pada makanan sumber karbohidrat. Salah satu bahan makanan yang mengandung serat cukup tinggi dan berpotensi menurunkan kadar glukosa darah adalah bengkoang.

Bengkoang adalah jenis buah-buahan golongan umbi-umbian yang banyak dikonsumsi oleh masyarakat di Indonesia, mudah didapat, dan memiliki harga yang relatif murah. Kandungan serat di dalam $100 \mathrm{gr}$ bengkoang sebanyak 0,64\% dan vitamin tertinggi yang terkandung di dalam bengkoang yaitu vitamin $\mathrm{C}$, selain itu serat yang terkandung di dalam bengkoang merupakan jenis serat larut air yaitu oligosakarida berupa inulin ${ }^{6}$. Inulin tersusun dari unit-unit fruktosa berserat pangan tinggi (lebih dari $90 \%$ ), selain itu inulin juga memberikan efek prebiotik yang paling baik dibandingkan prebiotik lain ${ }^{7}$. Inulin memiliki banyak manfaat antara lain mengurangi jumlah bakteri patogen dalam usus, meningkatkan kekebalan tubuh, dan dapat digunakan sebagai pengganti lemak dan gula pada produk makanan rendah kalori sehingga dapat digunakan sebagai alternatif bagi penderita diabetes ${ }^{8}$. Berdasarkan hasil penelitian dari uji laboratorium sari bengkoang mengandung senyawa flavonoid $26,455 \%$, vitamin C $13.86 \mathrm{mg}$, oligosakarida 44.04 gr, dan serat $3.94 \mathrm{gr}^{9}$.

Sari buah merupakan bagian dari pangan fungsional yang bermanfaat bagi tubuh apabila dikonsumsi. Pangan fungsional dapat berupa bahan pangan alami, bahan pangan yang telah ditambah komponen tertentu, bahan yang memiliki fungsi biologis yang telah dimodifikasidan bahan pangan dengan kombinasi dari ciri-ciri di atas ${ }^{7}$. Berdasarkan penelitian yang dilakukan pada wanita prediabetes yang diberikan sari bengkoang $250 \mathrm{ml}$ selama 21 hari, hasil menunjukkan bahwa pemberian sari bengkoang dapat menurunkan kadar glukosa darah puasa (GDP) sebesar 6 $\mathrm{mg} / \mathrm{dl}^{10}$.

Penelitian efek sari bengkoang sebelumnya memang pernah dilakukan pada wanita prediabetes, namun pada penderita Diabetes Mellitus tipe 2 belum pernah dilakukan. Berdasarkan hal tersebut peneliti ingin melakukan penelitian mengenai pengaruh pemberian sari bengkoang terhadap kadar glukosa darah puasa pada penderita Diabetes Mellitus tipe 2. 


\section{METODE}

Penelitian ini merupakan penelitian bidang gizi klinik dengan jenis penelitian yaitu eskperimen semu untuk menguji hipotesis yang ada sehingga diketahui pengaruh antar variabel. Rancangan penelitian yang digunakan yaitu non randomized pretest-postest control group design dengan melihat perubahan sebelum dan setelah dilakukan penelitian.

Populasi dalam penelitian adalah semua pasien berusia 40-60 tahun yang menderita diabetes mellitus tipe 2 di wilayah kerja Puskesmas Kedungmundupada bulan April sebanyak 60 orang. Sampel dalam penelitian ini adalah penderita diabetes mellitus tipe 2 tanpa komplikasi, tidak mengonsumsi obat hipoglikemik oral (OHO), tidak merokok dan tidak mengonsumsi alkohol. Pengambilan sampel dilakukan secara non randomized sampling. Jumlah sampel penelitian yaitu 36 orang yang terdiri 18 orang pada kelompok perlakuan dan 18 orang pada kelompok kontrol. Variabel penelitian terdiri dari variabel pengaruh (independent) yaitu sari bengkoang 320 gram dalam $200 \mathrm{ml}$ yang diberikan pada kelompok perlakuan selama 14 hari. Kelompok kontrol tidak diberikan apapun. Variabel terpengaruh (dependent) yaitu kadar glukosa darah puasa. Variabel pengganggu berupa presentase kecukupan energi, protein, lemak, karbohidrat dan serat.

Data identitas sampel meliputi nama, umur, tanggal lahir, jenis kelamin, alamat, pendidikan terakhir, pekerjaan, nomor hp dengan wawancara langsung menggunakan formulir identitas sampel. Data antropometri diperoleh melalui pengukuran berat badan dan tinggi badan yang dilakukan secara langsung oleh peneliti. Data asupan energi, protein, lemak, karbohidrat dan serat yag dikonsumsi diperoleh melalui food recall $3 \times 24$ jam pada hari ke 0 (sebelum intervensi), hari ke 3 , hari ke 7 dan hari ke 14 . Data kadar glukosa darah puasa diperoleh melalui pengecekan pada awal dan akhir penelitian menggunakan blood glucometer test merek Nesco yang dilakukan oleh mahasiswa analis kesehatan semester 6 dengan hasil ukur dalam $\mathrm{mg} / \mathrm{dl}$ dan berskala interval.

Analisis univariat dilakukan untuk mendeskripsikan karakteristik sampel dan karakteristik variabel yang diteliti berupa umur, jenis kelamin, pendidikan terakhir, asupan zat gizi sebelum dan selama intervensi. Analisis multivariat dilakukan untuk mengetahui pengaruh pemberian sari bengkoang yang dikontrol oleh asupan zat gizi (energi, protein, lemak, karbohidrat dan serat) dengan menggunakan uji ANOVA Repeated Measured.

\section{HASIL DAN PEMBAHASAN}

Penelitian dilakukan di wilayah kerja Puskesmas Kedungmundu, Kecamatan Tembalang, Kota semarang. Penelitian dilaksanakan selama 2 minggu dengan jumlah sampel sebanyak 36 orang yang diperoleh secara non randomized sampling.

\section{a. Karakteristik Subjek}

Sebagian besar subjek dalam penelitian ini adalah wanita dengan usia 51-60 tahun, dimana pada usia tersebut sebagian besar wanita sudah mengalami menopause. Wanita yang sudah mengalami menopause akan terjadi penurunan hormon estrogen dan progesteron. Peran kedua hormon ini memiliki kemampuan dalam meningkatan respons insulin di dalam darah. Pada saat masa menopause terjadi, maka respons insulin akan menurun akibat dari rendahnya hormon estrogen dan progesteron ${ }^{11}$.

Berdasarkan karakteristik usia, sebagian besar usia subjek berusia 51-60 tahun. Semakin bertambahnya usia maka resiko terkena penyakit diabetes mellitus tipe 2 semakin meningkat. Hal ini sejalan dengan penelitian yang telah dilakukan sebelumnya bahwa usia $\geq 45$ tahun berpeluang lebih besar menderita diabetes mellitus tipe 2 dibandingkan orang yang berusia $<45$ tahun ${ }^{5}$. Semakin bertambahnya usia, kemampuan jaringan dalam mengambil glukosa di dalam darah semakin menurun ${ }^{12}$. Menurut The Hormone Foundation, orang yang mengalami penuaan akan mengalami perubahan pada sistem endokrin, hal ini disebabkan karena sistem endokrin mengalami perubahan dalam proses produksi dan sekresi hormon termasuk hormon insulin sehingga pada orang yang semakin tua akan rentan terkena diabetes ${ }^{13}$.

Tingkat pendidikan merupakan salah satu unsur penting yang dapat mempengaruhi penerimaan informasi, karena pendidikan merupakan behavioral investmen jangka panjang. Penelitian ini didukung oleh penelitian lain yang menyebutkan bahwa tingkat pendidikan yang lebih rendah dikaitkan dengan risiko diabetes mellitus tipe 2 yang lebih tinggi baik pada laki-laki maupun perempuan. Tingkat pendidikan tidak memiliki pengaruh yang langsung terhadap kejadian diabetes mellitus tipe 2, akan tetapi dipengaruhi oleh faktor risiko lain riwayat merokok, BMI, dan aktivitas fisik $^{14}$.

Pendidikan yang dimiliki oleh seseorang akan mempengaruhi pengetahuan, 
yang mana dalam hal ini termasuk pengatahuan dalam memperoleh informasi mengenai gizi ${ }^{15}$. Pengetahuan juga akan mempengaruhi pola pikir seseorang dalam menganalisa suatu penyakit, karena dimungkinkan lebih mudah dalam menerima informasi pencegahan, dan memiliki kemampuan yang lebih tinggi untuk mengubah perilaku kesehatan $^{1614}$

Karakteristik Subjek Menurut Tingkat Energi, Protein, Lemak, Karbohidrat dan Serat

Hasil penelitian menunjukkan ratarata asupan energi dan karbohidrat pada kedua kelompok sudah dalam kategori baik. Rata-rata asupan protein pada kelompok perlakuan dan kelompok kontrol masih dalam kategori defisit berat (70\%). Rata-rata asupan lemak pada kelompok perlakuan dan kontrol dalam kategori lebih ( $\geq 120 \%$ ), asupan serat dalam kategori kurang yaitu $<25$ gram/hari dari rekomendasi asupan serat berdasarkan American Diabetes Association (ADA) sebesar $25-30$ gram $/$ hari $^{17}$.

Tabel 1. Karakteristik Subjek Menurut Jenis Kelamin, Usia Dan Pendidikan

\begin{tabular}{|c|c|c|c|c|}
\hline Variabel & \multicolumn{2}{|c|}{$\begin{array}{c}\text { Kelompok Rerlaknan } \\
\mathrm{n}=16\end{array}$} & \multicolumn{2}{|c|}{$\begin{array}{l}\text { Kelompok Kontrol } \\
n=18\end{array}$} \\
\hline $\begin{array}{l}\text { Ienis Kelamin } \\
\text { Bria }\end{array}$ & 3 & 18.8 & 5 & 27.8 \\
\hline Usia & & 81.2 & & \\
\hline $\begin{array}{l}\text { 40-50 tahun } \\
51-60 \text { tahum }\end{array}$ & 8 & 50 & ${ }^{3}$ & 16.7 \\
\hline 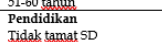 & & & & \\
\hline $\begin{array}{l}\text { Lidakak tamat SD } \\
\text { SD } / M \\
\text { SMP/MTs }\end{array}$ & $\begin{array}{l}3 \\
6 \\
2\end{array}$ & $\begin{array}{l}31.2 \\
37.5 \\
12.5\end{array}$ & 8 & $\begin{array}{l}44.4 \\
4.4 \\
56\end{array}$ \\
\hline $\begin{array}{l}\text { SMPP/MIs } \\
\text { SMA/SMK/sederaiat }\end{array}$ & ${ }_{3}^{2}$ & $\begin{array}{l}12.5 \\
18.8\end{array}$ & 1 & $\begin{array}{l}5.6 \\
5.6\end{array}$ \\
\hline
\end{tabular}

Tabel 2. Karakteristik Subjek Menurut Tingkat Energi, Protein, Lemak, Karbohidrat dan Serat

\begin{tabular}{|c|c|c|c|c|}
\hline \multirow{2}{*}{ Asupan Zat Gizi selama Interxensi } & \multicolumn{2}{|c|}{$\begin{array}{l}\text { Rerlakuan } \\
\text { (n=16) }\end{array}$} & \multicolumn{2}{|c|}{ 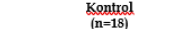 } \\
\hline & $\mathrm{n}$ & $\%$ & $\mathrm{n}$ & $\%$ \\
\hline Energi & & & & \\
\hline 70-79\% (Defisit sedang) & 1 & $\begin{array}{l}18.8 \\
6.3\end{array}$ & $\begin{array}{l}2 \\
4\end{array}$ & \\
\hline $\begin{array}{l}\text { 80-s9 (Defisititingan) } \\
\text { 80) }\end{array}$ & & & 2 & 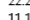 \\
\hline 90-119\% (Bail) & 5 & 31.2 & 7 & $\begin{array}{ll}30.9 \\
38.9\end{array}$ \\
\hline$\geq 120 \%$ (Lebilh) & 5 & 31.2 & 3 & 16.7 \\
\hline${ }_{<0 \% \text { Protein }}^{\text {Prefist berat) }}$ & 8 & 500 & 10 & \\
\hline $\begin{array}{l}<0 \% \text { \% (Defifitit berat) } \\
70-79 \% \text { (efisisit sed dang) }\end{array}$ & 1 & $\begin{array}{l}50.0 \\
6.3\end{array}-10$ & ${ }_{3}^{10}$ & $\begin{array}{l}53.9 \\
16.7\end{array}$ \\
\hline so-s9 (Refisit ringan) & & 12.5 & 1 & 5.6 \\
\hline $\begin{array}{l}\text { 90-119\% (Bail) } \\
\text {-120 (Bakl }\end{array}$ & & 31.2 & 2 & 11.1 \\
\hline 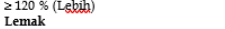 & & & 2 & \\
\hline$<70 \%$ (Defisist berat) & 3 & 18.8 & 1 & 5.6 \\
\hline 70-79\% (Refisist sedang) & & 6.3 & 5 & 27.7. \\
\hline $\begin{array}{l}\text { S0-s9 (Defisitit ringan) } \\
90-111 \% \text { (Bak) }\end{array}$ & 1 & 6.3 & 1 & 5.6 \\
\hline 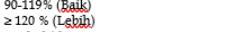 & ${ }_{9}^{2}$ & $\begin{array}{l}12.4 \\
56.2\end{array}$ & ${ }_{9}^{2}$ & ${ }_{50.0}^{11.1}$ \\
\hline $\begin{array}{l}\text { Karbohidrat } \\
<0 \% \text { (pefisit berat) }\end{array}$ & & & & \\
\hline $\begin{array}{l}<0 \% \text { \& (Defisitit berat) } \\
70-79 \% \text { (Refisit tedeng) }\end{array}$ & $2^{2}$ & $\begin{array}{l}12.5 \\
12.5\end{array}$ & ${ }_{4}^{2}$ & $\begin{array}{l}11.1 \\
22.2 \\
2.2\end{array}$ \\
\hline s0-89 (Defisisit ringan) & 2 & 12.5 & 2 & 11.1 \\
\hline 90-119\% (Baik) & $s$ & 50.0 & 7 & 38.99 \\
\hline & & & & \\
\hline$<25 \mathrm{gr}$ (Kurang) & 16 & 100 & 18 & 100 \\
\hline
\end{tabular}

Karakteristik Subjek Menurut Asupan Energi, Protein, Lemak, Karbohidrat dan Serat

Hasil penelitian menunjukkan bahwa rata-rata asupan energi sebelum intervensi pada kelompok perlakuan dan kontrol yaitu $1451.9 \mathrm{kkal}$ dan $1421.0 \mathrm{kkal}$, protein 43.6 gramdan 40.2 gram, lemak 53.1 gram dan 52.3 gram, karbohidrat 205.8 gram dan 200.5 gram, serat 10.1 gram dan 10.4 gram. Rata-rata asupan energi setelah intervensi pada kelompok perlakuan dan kontrol 1439.5 kkal dan $1541.8 \mathrm{kkal}$, protein 40.4 gram dan 45.6 gram, lemak 54 gram dan 55.8 gram, karbohidrat 203.3 gram dan 220.6 gram, serat 14.7 gram dan 10 gram.

Rata-rata asupan serat perhari pada kelompok yang diberi sari bengkoang yaitu 14.7 gram, jumlah tersebut lebih besar daripada kelompok yang tidak diberi sari bengkoang yaitu sebesar 10 gram.

Akan tetapi angka ini masih sangat jauh dari anjuran kebutuhan serat perhari yang dianjurkan menurut American Diabetes Association yaitu sebesar 25-30 gram/hari ${ }^{17}$.

Tabel 3. Karakteristik Subjek Menurut Asupan Energi, Protein, Lemak, Karbohidrat dan Serat

\begin{tabular}{|c|c|c|c|c|c|c|c|c|}
\hline \multirow{2}{*}{ Xariabel } & \multicolumn{4}{|c|}{$\begin{array}{c}\text { Kelompok Rerlakuan } \\
(\mathbf{n}=16)\end{array}$} & \multicolumn{4}{|c|}{$\begin{array}{c}\text { Kelompok Kontrol } \\
(\mathrm{n}=18)\end{array}$} \\
\hline & $\begin{array}{c}\text { Rata- } \\
\text { rata }\end{array}$ & SD & Min & Max & Rata-rata & SD & Min & Max \\
\hline \multicolumn{8}{|c|}{ Sebelum Interxensi } & \\
\hline $\begin{array}{l}\text { Energi } \\
\text { Protein }\end{array}$ & $\begin{array}{c}1451.9 \\
43.6\end{array}$ & $\begin{array}{l}251.4 \\
11.3\end{array}$ & $\begin{array}{l}1031 \\
23.7\end{array}$ & $\begin{array}{l}1875 \\
62.6\end{array}$ & & $\begin{array}{l}482.6 \\
17.0\end{array}$ & $\begin{array}{l}834 \\
16\end{array}$ & $\begin{array}{l}2293 \\
90.8\end{array}$ \\
\hline Lemak & 53.1 & 21.6 & 26.2 & 96.1 & 52.3 & 27.1 & 18.5 & 120.8 \\
\hline Sarbehidrat & 205.8 & 38.9 & 145 & 271 & 200.5 & 60.9 & 122 & 322.8 \\
\hline \multirow{2}{*}{\multicolumn{9}{|c|}{ Selama Interxensi }} \\
\hline & & & & & & & & \\
\hline Energi & 1439.5 & 284 & 1026 & 1939 & 1541.8 & 385.9 & 1010 & 2256 \\
\hline Protein & 40.4 & 9.5 & 25.1 & 58.5 & 45.6 & 17.4 & 20.1 & 92.3 \\
\hline Lemak & 54 & 20.7 & 23.7 & 91.3 & 55.8 & 23.1 & 27.5 & 112.2 \\
\hline Sarbobidrat & 203.3 & 32.6 & 152.4 & 253.2 & 220.6 & 42.5 & 156.2 & 323.7 \\
\hline & 14.7 & & & & 10 & 3.5 & & 18 \\
\hline
\end{tabular}

\section{b. Analisis Multivariat}

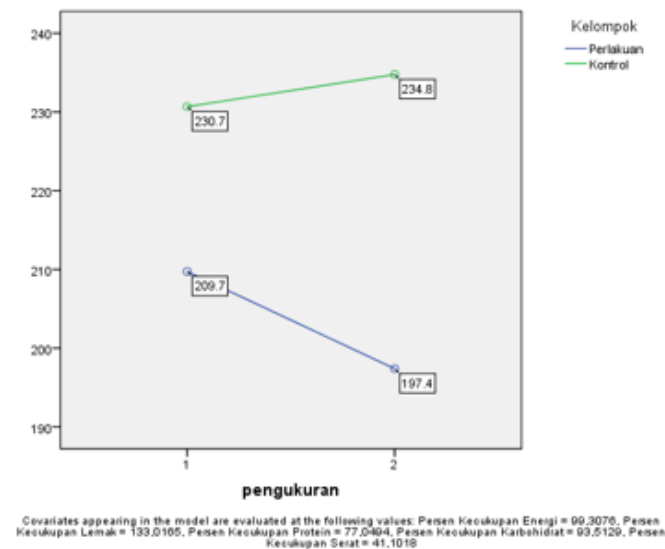

Gambar 1. Pengaruh Pemberian Sari Bengkoang Terhadap Kadar Glukosa Darah Puasa yang Dikontrol dengan Asupan Zat Gizi

Hasil uji statistik menunjukan bahwa pemberian sari bengkoang selama 14 hari berpengaruh tidak signifikan terhadap 
penurunan kadar glukosa darah puasa $(p=$ 0.344). Gambar 1 menunjukkan bahwa kadar glukosa darah puasa pada kelompok perlakuan mengalami penurunan sebesar $12.3 \mathrm{mg} / \mathrm{dl}$ dan pada kelompok kontrol mengalami peningkatan sebesar $4.1 \mathrm{mg} / \mathrm{dl}$, akan tetapi penurunan tersebut secara statistik tidak signifikan ( $p>0.05$ ). Penelitian ini sejalan dengan penelitian sebelumnya yang menyebutkan bahwa pemberian sari bengkoang sebanyak $250 \mathrm{ml}$ selama 21 hari secara signifikan dapat menurunkankan kadar glukosa darah puasa sebesar $6 \mathrm{mg} / \mathrm{dl}$ atau sebesar $5.53 \%{ }^{10}$.

Sari bengkoang memiliki kandungan oligosakarida dalam bentuk inulin yang diketahui berperan dalam menurunkan kadar glukosa darah. Berdasarkan uji laboratorium di UPT Laboratorium Ilmu Gizi dan Pangan Universitas Muhammadiyah Semarang dalam penelitian Yasmina (2013), kandungan oligosakaraida dalam 320 gram bengkoang sebanyak 44.04 gram $^{10}$. Sedangkan menurut penelitian oleh Mulyani, dkk, (2004), kandungan inulin dalam filtrat umbi bengkoang sebesar $4.41 \%{ }^{18}$. Penelitian secara in vivo yang dilakukan pada tikus dengan pemberian inulin (50 mg/kg BB dan $100 \mathrm{mg} / \mathrm{kg} \mathrm{BB}$ ) sebesar $60.73-63.4 \%$ pada minggu ke-4 menunjukkan penurunan kadar glukosa darah $(p<0.05)^{19}$.

Inulin merupakan jenis serat larut air yang tidak dapat dicerna oleh enzim di saluran pencernaan akan tetapi dapat difermentasi di usus besar dan dapat digunakan sebagai terapi hipoglikemik dengan cara meningkatkan sekresi insulin yang dirangsang oleh sel $\beta$ pankreas dan memperbaiki sensitivitas insulin $^{20}$. Mekanisme inulin dalam penurunan kadar glukosa darah seperti halnya serat larut air lainnya melalui peningkatkan viskositas lambung sehingga memperlambat pencernaan dan menunda pengosongan lambung. Penelitian oleh Robert, dkk, (2012) menyatakan bahwa peningkatan asupan serat berpengaruh dalam memperbaiki kadar glukosa darah puasa yaitu dengan menurunkan kadar sebesar 0.85 $\mathrm{mmol} / \mathrm{L}$ dan $\mathrm{HbA} 1 \mathrm{c}$ mengalami penurunan $0.26 \%{ }^{21}$. Mengonsumsi tinggi serat dapat membantu sel-sel lebih sensitif terhadap insulin yang mengatur kadar glukosa darah. Mekanisme serat larut air di dalam saluran pencernaan akan memperlambat aliran glukosa ke dalam darah sehingga konsentrasi glukosa dalam darah akan stabil. Serat juga membuat rasa kenyang yang lebih lama di dalam tubuh sehingga akan mengurangi rasa lapar lebih lama ${ }^{13}$.
Sari bengkoang yang diperoleh dari 320 gram bengkoang juga mengandung kandungan vitamin C sebesar $13.86 \mathrm{mg}$. Kandungan vitamin $\mathrm{C}$ di dalam sari bengkoang merupakan kandungan vitamin yang paling tinggi dibandingkan kandungan vitamin yang lain ${ }^{10}$. Menurut penelitian oleh Mutiarani (2017), pemberian dosis vitamin $C$ pada tikus Wistar sebesar $1.62 \mathrm{mg} /$ hari $2 \mathrm{mg} /$ hari atau sekitar $90 \mathrm{mg} /$ hari untuk dosis pada manusia yang diberikan selama 40 hari memberikan pengaruh terhadap kadar insulin $(p=0.017)^{22}$. Vitamin $C$ merupakan antioksidan non enzimatis, dan berperan dalam melindungi kerusakan sel yang diakibatkan oleh radikal bebas yaitu auto oksidasi glukosa dan glikosilasi protein yang terlibat dalam pembentukan stress oksidatif. Mekanisme vitamin C dalam penurunan kadar glukosa darah yaitu dengan cara mengurangi toksisitas glukosa yang berkontribusi dalam mencegah penurunan masa sel $\beta$ dan kadar inulin. Vitamin $C$ akan memodulasi kerja insulin yang disebabkan oleh peningkatan metabolisme glukosa nonoksidatif, sehingga akan menurunkan kadar glukosa darah ${ }^{23}$.

\section{KESIMPULAN}

Pemberian sari bengkoang yang dikontrol oleh asupan energi, protein, lemak, karbohidrat dan serat secara statistik berpengaruh tidak signifikan ( $p>0.05$ ) terhadap penurunan kadar glukosa darah puasa setelah pemberian intervensi selama 14 hari.

\section{SARAN}

Masyarakat dapat mengonsumsi sari bengkoang sebagai salah satu diet alternatif bagi penderita diabetes mellitus. Dapat menggunakan kombinasi dengan bahan lain untuk meningkatkan kandungan serat di dalam produk.

\section{DAFTAR PUSTAKA}

1. Soebroto I. Hidup Bahagia Dengan Diabetes. I. Bantul, Yogyakarta: Bangkit; 2015. 1-180 p.

2. World Health Organization. Global Report on Diabetes [Internet]. Vol. 978, Isbn. 2016. 88 p. Available from:http://www.who.int/about/licensing/\% $5 \mathrm{C}$

nhttp://apps.who.int/iris/bitstream/10665/2 04871/1/9789241565257_eng.pdf.

3. Nam Han Cho, Whiting D, Forouhi N, Guariguata L, Hambleton, lan, et al. IDF Diabetes Atlas. In: David Cavan, Fernandes J 
da R, Makaroff L, Ogurtsova K, Webber S, editors. International Diabetes Federation. Seventh. 2015. p. 144.

4. Dinas Kesehatan Provinsi Jawa Tengah. Profil Kesehatan Provinsi Jawa Tengah [Internet]. Dinas Kesehatan Provinsi Jawa Tengah. 2015. 48-49

p. Availablefrom:dinkesjatengprov.go.id/v2015/ dokumen/profil2015/Profil_2015_fix.pdf

5. Palimbunga TM, Ratag BT, Kaunang WPJ. Faktor-Faktor Yang Berhubungan Dengan Kejadian Diabetes Melitus Tipe 2 Di RSU Gmim Pancaran Kasih Manado. 2016;1-11.

6. PERKENI. Konsensus Pengendalian dan Pencegahan Diabetes Melitus Tipe 2 di Indonesia 2015 [Internet]. Perkeni. 2015. 78 p. Available from: http://pbperkeni.or.id/doc/konsensus.pdf

7. Kamsina. Pengaruh Konsentrasi Sari Buah Dan Jenis Gula Terhadap Mutu Minuman Fungsional Dari Bengkoang (Pachyrhizus erosus). Litbang Ind. 2014;4(1):19-27.

8. Sundari E, Desfitri ER, Martynis M, Praputri E. Identifikasi Dan Kondisi Ekstraksi Inulin Dari Umbi Dahlia Di Sumatera Barat. 2014;(September).

9. Wimala $\mathrm{M}$, Retaningtyas $\mathrm{Y}$, Wulandari $\mathrm{L}$. Penetapan Kadar Inulin dalam Ekstrak Air Umbi Bengkoang ( Pachyrhizus erosus L .) dari Gresik Jawa Timur dengan Metode KLT Densitometri ( Inulin Determination of Yam Bean Tuber ( Pachyrhizus erosus L .) from Gresik East Java using TLC Densitometry ). eJurnal Pustaka Kesehat. 2015;3(1):61-5.

10. Yasmina AR, Probosari E. Perbedaan Kadar Glukosa Darah Puasa Sebelum dan Setelah Pemberian Sari Bengkoang (Pachyrrizus erosus) Pada Wanita Prediabetes. J Nutr Coll. 2014;3:440-6.

11. Meidikayanti W, Wahyuni CU. Hubungan Dukungan Keluarga Dengan Kualitas Hidup Diabetes Melitus Tipe 2 Di Puskesmas Pademawu. J Berk Epidemiol. 2017;(August):240-52.

12. Suiraoka IP. Penyakit Degenaratif. Yogyakarta: Nuha Medika; 2012.

13. Leoni AP. Hubungan Umur, Asupan Protein, Dan Faktor Lainnya Dengan Kadar Gula Darah Puasa Pada Pegawai Satlantas Dan Sumda Di Polresta Depok Tahun 2012. 2012.

14. Sacerdote C, Ricceri F, Rolandsson O, Baldi I, Chirlaque $M$, Feskens $E$, et al. Lower educational level is a predictor of incident type 2 diabetes in European countries: The EPIC-InterAct study. J Epidemiologi. 2012;(June):1162-73.

15. Factors D, Diversity D. Review Faktor
Determinan. Gizi dan Pangan. 2007;2(2):5574.

16. Amilia $Y$, Saraswati LD, Epid M, Muniroh $M$, Med MS, Ph D, et al. Hubungan Pengetahuan , Dukungan Keluarga Serta Kejadian Ulkus Kaki Diabetes ( Studi di Wilayah Kerja Puskesmas Ngesrep Semarang ). J Kesehat Masy. 2018;6.

17. IKAPI. Bebas Masalah Berat Badan. 1st ed. Yogyakarta: Kanisius; 2009. 7-9 p.

18. Mulyani T, A SS. Kajian Peran Susu Skim Dan Bakteri Asam Laktat Pada Minuman Sinbiotik Umbi Bengkoang (pachyrrhizus erosus). 2004.

19. Byung-Sung P. Effect of oral administration of jerusalem artichoke inulin on reducing blood lipid and glucose in STZ-induced diabetic rats. Vol. 10, Journal of Animal and Veterinary Advances. 2011. p. 2501-7.

20. Putri DA. Manfaat inulin bagi kesehatan dan aplikasinya. 2013.

21. Post RE, lii $A G M$, King $D E$, Simpson $K N$. Dietary Fiber for the Treatment of Type 2 Diabetes Mellitus: A Meta-Analysis. 2012;25(1).

22. Mutiarani AL. Pengaruh Pemberian Vitamin C , Vitamin E , Dan Kromium ( Cr3 + ) Terhadap Kadar Insulin Tikus Wistar Yang Diinduksi Aloksan. Med Heal Sci. 2017;1(1):14-21.

23. Winarsi $H$, Sasongko ND, Purwanto $A$, Nuraeni I. Cardamom Extract Leaves Decreased Atherogenic Indexs and Blood Glucose Level of Diabetic Rats AlloxansInduced. J Agritech. 2013;33(3):273-80. 